\title{
Metacognitive Strategies to Chinese College English Learners: A Real Gold or only with a Golden Cover
}

\author{
$\mathrm{Li} \mathrm{Gao}^{1}$ \\ ${ }^{1}$ School of Foreign Studies, Henan Polytechnic University, Jiaozuo, Henan, China \\ Correspondence: Li Gao, School of Foreign Studies, Henan Polytechnic University, Jiaozuo, Henan, China. \\ E-mail: gaolihpu@gmail.com
}

Received: July 11, 2013

Accepted: August 12, $2013 \quad$ Online Published: November 12, 2013

doi:10.5539/jel.v2n4p71

URL: http://dx.doi.org/10.5539/jel.v2n4p71

\begin{abstract}
With the advent of computer-assisted autonomous learning, English listening has become more challangable to Chinese college English learners. Metacognitive strategies, often adopted in process-based approach emphasizes more on the listening process. This paper discusses the feasibilty of metacognitive strategies in English listening instruction in Chinese universities by synthesizeing and appraising the empirical research about metacognition in EFL/ESL listening. Through contrast and comparison, the possible problems existing in these current research and implications for future research and teaching are given at the end of the paper. Finally, the applicablity of metacognitive strategies is analyzed under the context of Chinese college English instruction.
\end{abstract}

Keywords: metacognition, strategy, EFL/ESL listening, Chinese college English instruction

\section{Introduction}

Listening is a mentally complicated cognitive process including receptive, constructive and interpretive aspects of cognition, which allows a person to understand spoken language (Rost, 2005). This process involves a great deal of mental activity on the part of the listener, especially on the part of a second or foreign language (SL/FL) listener. Thus, a focus on the cognitive listening process is urgently required.

Process-based approach attaches more emphasis on what happens during learner's listening process. It observes the difficulties or breakdowns learners encounter in the process, analyzes the difficulities and finally provides learners with effective solutions. In this way, learners are enabled to tackle their listening problems without being left alone to do nothing but listen harder. Metacognitive strategies, for its attribute in facilitating learners' autonomous study, have been receiving much attention in China with the advent of computer-assisted autonomous study of English listenign and speaking in universities.

This paper is to discuss the feasibility of metacognitive strategies in English listening instruction in Chinese universities by reviewing the mainly credited literature about metacognitive strategies in second language listening aiming to discover the research gap concerning this topic and acquire some pedagogical implication.

\section{Metacognition and Language Learning}

\subsection{Definition of Metacognition}

The term "metacognition" is most associated with American psychologist John Flavell, a foundation researcher in metacognition, who first formally used "metacognition" in the title of his article entitled "Metacognitive Aspects of Problem Solving" (Flavell, 1976, p. 231). Metacognition, according to Flavell (1976) can be defined as follows:

In any kind of cognitive transaction with the human or non-human environment, a variety of information processing activities may go on. Metacognition refers, among other things, to the active monitoring and consequent regulation and orchestration of these processes in relation to the cognitive objects or data on which they bear, usually in service of some concrete goal or objective. (p. 232).

To put it simple, metacognition is kind of intentional higher mental control over one's own thinking process. Flavell's definition was followed by many others, often portraying different emphases on mechanisms and processes associated with metacognition. For example, Cross and Paris (1988) identified two broad categories of mental activities in metacognition: self-appraised knowledge about cognition and self-management of one's 
thinking. Although the fact is that there is much debate over what exactly metacognition is, "all emphasize the role of executive processes in the overseeing and regulation of cognitive processes" (Livingston, 1997). In this paper, the concept of metacognition accords that given by Livingston.

\subsection{Matecognitive Strategies}

Flavell (1987) proposed a taxonomic categorization of the components: metacognitive knowledge and metacognitive experience. Jausovec (2008) remarked there are two components: metacognitive knowledge and metacognitive control. Metacognitive knowledge is that part of one's knowledge that refers to cognitive matters (Flavell, 1987; Jausovec, 2008), namely one's knowledge about how one's cognition operates, which consists of knowledge of three variables: person, task and strategy. Metacognitive control "pertains to how one controls one's cognitive operations" (Jausovec, 2008, p. 46). Metacognitive knowledge and control do not operate independently but are mutually influenced. As aforementioned, metacognitive strategy, one of the three variables of metacognitive knowledge, refers to knowledge about cognitive strategies use and cognitive procedures in pursuing a certain goal. It involves "planning learning, monitoring the process of learning, and evaluating how successful a particular strategy is" (Tohidian, 2009, p. 63). With regard to SL/FL acquisition, it pertains to the notion that L2 learners are able to think consciously about how they learn and how successfully they are learning.

\subsection{Metacognitive Knowledge and Language Acquisition}

It is conceived that the adoption of learning strategies facilitates language learning and language learning is dependent on using strategies (Cohen, 2003). Metacognitive knowledge plays a crucial role in many cognitive activities related to language use and language acquisition (Flavell, 1979) and it characterizes how efficient learners learn (Wenden, 1998). What's more, the failure of inefficient learners can be attributed more to that they do not know when and where to select which strategy than to that they have less idea of cognitive strategies (Wu, 1994, cited in Yang, 2003). Namely, the inefficient learners have less metacognitive awareness. Field (1998) confirms the necessity of strategy use in listening, among which metacognitive strategies should be a component of instructional programs (Wenden, 1998).

\section{Critical Literature Review of Metacognitive Strategies in EFL/ESL Listening}

\subsection{Literature Review of the Previous Research Studies}

Research was directed to investigate listening strategies from the late 1980s (Chamot, 1987; Vandergrift, 1999) after experiencing a decades-long journey from its focus on the important role of listening in second language acquisition to its emphasis on listening strategies. The relevant studies paid close attention to the feasibility of metacognitive strategies in FL/SL acquisition and how to practice it.

Based on the factual situation that listening plays an important role in the development of learners' second/foreign language but few insights are there about the process of listening and the way it is learnt, Goh (1997) carried out an empirical study of metacognitive awareness with a group of 40 Chinese EFL learners in Singapore, who were ready for college, through asking them to write listening diaries in which their mental processes during listening were reflected. It was found that many of them had clear ideas about the three aspects of metacognitive knowledge: person (their own role and performance as second language listeners), task (the demands and procedures of second language listening) and strategy (strategies adopted in listening). Goh, therefore, suggested listening classes should involve students in thinking not just about the listening content but more about the listening process to enhance students' awareness of learning to listen. For example, learners should be provided with more opportunities to share their listening reflection with other learners. This study provided the further confirmation that language learners have metacognitive awareness, of which instructor should help to make use to facilitate listening development. However, it remained ambiguous that what the real situation of strategies use among language learners are.

In presenting findings from research into strategies and tactics use of EFL learners from China, Goh (1998) noted that both high-ability and low-ability learners adopted cognitive and metacognitive strategies and tactics, but the high-ability learners used more strategies and tactics than the low-ability ones. In addition, both used less metacognitive strategies than cognitive strategies. Goh believed the best instructional way is to guide learners to develop greater metacognitive knowledge about learning to listen. However, with the presence of both cognitive and metacognitive strategies in the listening process of both parties, it does not appear so reasonable to draw the conclusion that the high-ability learners outperformed the low-ability ones just owing to their adoption of more metacognitive strategies. The issue that, cognitive or metacognitive strategy, which weighs more for high-ability in listening finds not convincing evidence from Goh. 
Since metacognitive awareness does exist and facilitate learners in listening, what are teachers supposed to do in listening instruction? With the similar consideration of how listening is taught, Vandergrift (1999) restated the primary role of metacognitive strategy in developing listening comprehension by reviewing the previous research, and put forward some detailed suggestions to help teachers foster the acquisition of metacognitive strategies; develop meta-strategic awareness; incorporate pre-listening and post-listening activities; teach students to plan for the successful completion of a listening task, to monitor their comprehension during a listening task, to evaluate the approach and outcomes of a listening task; development and use of listening comprehension checklists.

In addition to the research with adult learners, research on younger language learners (Vandergrift, 2002) demonstrated that reflection on the process of listening could help students develop metacognitive knowledge and achieve greater success.

In order to fill the gap between L2 listening theory and practice, Vandergrift (2003) made a small-scale study which involved two groups of university students registered in the second semester of a beginner-level FSL (French as a second language) course. The two tasks designed in this research was to systematically lead students through the process of listening as part of regular listening activities, and the results of this study affirmed that the systematic consciousness-raising led students to become more sensitive to the process of listening and to develop metacognitive knowledge about L2 listening. Besides, the benefits of promoting language classroom with a dual focus where students are taught both learning language and learning processes were affirmed. Proceeding from Vandergrift (2003) in which research was carried out with 41 university students taking French as second language, Goh and Yusnita (2006) also attempted to further explore the benefits of metacognitive training in L2 listening by conducting a small-scale study with primary school students in Singapore. The similar result was reached. Goh raised the term metacognition instruction in this paper and stated by focusing explicitly on person, task, and strategy knowledge. Metacognitive instruction would raise students' awareness of listening process and this can facilitate them to generate a range of skills and strategies in listening.

After introducing metacognitive instruction in L2 listening, Goh (2008) explained in detail the theoretical rationale and identified principles for carrying out metacognitive instruction, as well as outline general instructional objectives and two learning activities for this purpose. It can be a generalization of the recent research into applying metacognitive strategies to L2 listening instruction.

Research studies of metacognitive strategies in ESL/EFL listening did not attract much attention in China until the end of 1990s. As to the research on metacognitive strategies in ESL/EFL listening, most of the research studies carried out in China arrived at the consensus with those overseas research - metacognitive strategies play a positive and important role in developing EFL listening comprehension.

Wen (1995) pointed out the ineffective learners failed not for lack of cognitive ability but for language learning ability like self-awareness and macro-adjustment. Actually, it has much to do with metacognition. Then, from around the beginning of the new millennium, research studies appeared one after another, but the total number was not large and the innovation in theory was hard to find.

Some research (Zhou, 2001; Chen, 2005; Liu, 2006) discussed metacognitive strategies in EFL listening in theory, explained how teachers could nurture the development of students' metacognitive strategies by applying pre-class, while-class and post-class activities under factual teaching context. Along with the theoretical discussion, there also came out some research (Yang, 2003; Feng, 2003; Tian, 2003; He, 2005; Shi, 2005; Luo, 2005) which attempted to argue whether metacognitive strategies can really promote EFL listening ability. Different subjects were selected in these empirical studies, such as English majors in Yang (2003) and Luo (2005), 45 senior middle school students in Feng (2003), college non-English majors in Tian (2003), He (2005) and Shi (2005). All the findings of these studies were consistent and confirmed that it was important to apply metacognitive strategies to EFL listening for language learners. Whether adult learners or middle school learners, who received a certain period of training in using metacognitive strategies, showed consensus that their metacognitive awareness was enhanced and they began to make use of it by themselves because the strategies were useful.

Besides, metacognitive strategy was also discussed with regard to its role in constructing learning autonomy. Lin (2002) analyzed the metacognitive ability of unsuccessful listeners by discussing their metacognitive characteristics to reveal the reason for their failure. It indicated successful learners have the ability in planning, monitoring and evaluating their learning, which is regarded as metacognitive awareness, and it is the same situation in EFL listening. Those unsuccessful learners can get improvement by enhancing metacognitive 
awareness. Actually, given the executive aspects of metacognition, it is believed to construct autonomy in learners (Zeng, 2007).

\subsection{Discussion of the Previous Research}

Through this short review of research into metacognitive strategies in second language listening, the status of metacognition in L2 listening seems to be firmly established. Language learners can get much offer from metacognitive instruction (Goh, 2008) - it can promote learners to regulate their comprehension and achieve successful comprehension. Most previous research studies, however, are small-scale ones carried out within a comparatively short period (Cross, 2009). The progress in listening ability or listening awareness those subjects made in the current research may not exhibit the long-term sustainability thoroughly, since cognitive process is mentally sophisticated and hard to detect directly and quickly. Moreoever, it is of possibilty that the short-term effect shields the real influence with a bright cover. Delicately designed research studies, which involve larger sample size are suggested to be given a try for a long-term influence of metacognitive strategies training upon second language listening development.

\section{Its applicability in Chinese Context}

\subsection{Chances of Success in Application}

Chinese learners in universities find a golden kont in English listening, even those with high English proficiency in reading and writing, so it will evoke their motivation since metacognitive strategies can work within a comparatively short period as verified by the aforementioned studies. Based on the current tendency that learners have to undergo computer-assisted autonomous learning of English listening and speaking, some activities in metacognitive instruction, say listening diaries, can be very useful under the circumstances of limited instructional time. Related research (Ding, 2011) shows that Chinese college students are short of enough metacognitive awareness which will greatly impede their English computer-assisted autonomous learning. This methods like listening diary are believed to be able to play the role of a crunch in time for Chinese learners if designed appropriately by us teachers.

Although, there are many blocks in implementing metacognitive instruction because of no listening class time allocated for non-English maojors, it will benefit Englsih majors a lot with systematic metacognition training.

\subsection{Chances of Failure in Application}

Language learning context in China is not quite similar to those delineated in the aforementioned studies. First, Chinese and English belong to different language systems so the results, which were acquired frrom the studies carried out among learners whose first language, say French, shares siilarities with English, may not work among Chinese students. Second, college English teachers like me have no classroom and no time to provide enough metacognitive instruction to learners with the advent of autonomous study of listening and speaking. Though the possibility is that I can offer help during the tutoring time after class, the question is that how many lerners are actually willing to collect their problems and trun to teachers for help and how many teachers are really quite ready for staying longer to provide help. Where something can go wrong, something will go wrong. In addition, the more important is that metacognitive instrcution is supposed to be implemented systematically, so without regular meeting, it is of little chance to reach satisfactory end.

\section{References}

Chamot, A. U. (1987). The learning strategies of ESL students. In A. L. Wenden, \& J. Rubin (Eds.), Learner strategies in language learning (pp. 71-83). London: Prentice Hall.

Chen, J. (2005). On application of metacognition to multi-media English listening class. Foreign Language Research, 89, 44-46 (in Chinese).

Cohen, A. D. (2003). The learner's side of foreign language learning: Where do styles, strategies, and tasks meet? IRAL, 41(4), 279-291.

Cross, D. R. (1988). Paris Scott G. Developmental and instructional analyses of children's metacognition and reading comprehension. Journal of Educational Psychology, 80(2), 131-142.

Cross, J. (2013). Effects of listening strategy instruction on news videotext comprehension. Language Teaching and Research, 13(2), 151-176. http:// dx.doi.org/10.1177/1362168809103446

Ding, X. (2011). On non-English majors' listening metacognitive awareness in autonomous learning. Journal of Hunan University of Science and Technology (Social Science Edition), 14(3), 141-145 (in Chinese). 
Feng, Y. (2003). Metacognitive strategy in listening comprehension. English Teaching and Research Notes, 11, 3-5. (in Chinese).

Field, J. (1998). Skills and Strategies: Towards a New Methodology for Listening. ELT, 52(2), 110-118.

Flavell, J. H. (1976). Metacognitive aspects of problem solving. In L. B. Resnick (Ed.), The Nature of Intelligence (pp. 231-236). Hillsdale, NJ: Erlbaum.

Flavell, J. H. (1987). Speculations about the nature and development of metacognition. In F. E. Weinert, \& R. H. Kluwe (Eds.), Metacognition, motivation, and understanding (pp. 21-29). Hillsdale, New Jersey: Lawrence Erlbaum.

Goh, C. (1997). Metacognitive awareness and second language listeners. ELT, 51(4), 361-369. http://dx.doi.org/10.1093/elt/51.4.361

Goh, C. (1998). How ESL learners with different listening abilities use comprehension strategies and tactics. Language Teaching Research, 2(2), 124-127. http://dx.doi.org/10.1191/136216898667461574

Goh, C. (2006). Taib Yusnita. Metacognitive instruction in listening for young learners. ELT, 60(3), 222-232. http://dx.doi.org/10.1093/elt/ccl002

Goh, C. (2008). Metacognitive instruction for second language listening development: Theory, practice and research implications. RELC Journal, 39(2), 188-213. http://dx.doi.org/10.1177/0033688208092184

He, Z. (2005). An Experiential Study on Metacognitive Strategy Training in Listening Class. CAFLE, 102, 56-61 (in Chinese).

Jausovec, N. (2008). Metacognition-A Psychological Perspective. In F. M. Shaughnessy, \& C. Kleyn-Kennedy (Eds.), Meta-cognition: A Recent Review of Research, Theory and Perspectives (pp. 45-62). New York: Nova Science.

Lin, Q. (2002). A metacognitive study on unsuccessful listeners. Foreign Language World, 2, 40-44 (in Chinese).

Livingston, J. A. (2011). Metacognition: An Overview. Retrieved November 10, 2011, from http://gse.buffalo.edu/fas/shuell/cep564/metacog.htm

Liu, N. (2006). The application of metacognitive theory in the improvement of English listening. Journal of $X i$ 'an International Studies University, 14(2), 48-50 (in Chinese).

Luo, L. (2005). The application of metacognitive strategies in listening comprehension. Journal of Southwest University for Nationalities (Social Science Edition), 26(4), 336-338 (in Chinese).

Rost, M. (2005). L2 Listening. In E. Hinkel (Ed.), Handbook of research in second language teaching and learning (pp. 503-527). New Jersey: Lawrence Erlbaum.

Shi, L. (2005). Metacognitive awareness and second language listeners. CAFLE, 106, 55-59 (in Chinese).

Tian, X. (2003). Metacognition and EFL listening instruction. Journal of Sichuan International Studies University, 19(6), 139-143 (in Chinese).

Tohidian, I. (2006). A glossary of second language acquisition (p. 63). New York: Nova Science.

Wen, Q. (1995). The differences in learning strategies of successful learners and unsuccessful Learners. Foreign Language Teaching and Research, 3, 35-39 (in Chinese).

Wen, Q., \& Wang, L. (2004). Challenging the effectiveness of L2 learning strategy studies. Foreign Language World, 2, 2-7 (in Chinese).

Wenden, L. A. (1998). Metacognitive knowledge and language learning. Applied Linguistics, 19(4), 515-537. http://dx.doi.org/10.1016/S0346-251X(99)00043-3

Vandergrift, L. (1999). Facilitating second language listening comprehension: Acquiring Successful Strategies. ELT, 53(3), 168-176. http://dx.doi.org/10.1093/elt/53.3.168

Vandergrift, L. (2002). 'It was nice to see that our predictions were right': developing metacognition in L2 listening comprehension. The Canadian Modern Language Review, 58(4), 555-575. http://dx.doi.org/10.3138/cmlr.58.4.555

Vandergrift, L. (2003). From prediction through reflection: Guiding students through the process of L2 listening. The Canadian Modern Language Review, 58(3), 425-440. http://dx.doi.org/10.3138/cmlr.59.3.425 
Yang, J. (2003). Meta-cognitive strategy training in listening class. Foreign Language Education, 24(4), 65-69 (in Chinese).

Zeng, Y. (2007). Metacognitive instruction in listening: A study of Chinese non-English major undergraduates. (Unpublished Master thesis, Singapore: Nanyang Technological University).

Zhou, Y. (2001). Use metacognitive strategies in listening comprehension. MIFL, 79, 40-42 (in Chinese).

\section{Copyrights}

Copyright for this article is retained by the author(s), with first publication rights granted to the journal.

This is an open-access article distributed under the terms and conditions of the Creative Commons Attribution license (http://creativecommons.org/licenses/by/3.0/). 